\title{
Do Broilers Prefer to Eat from a Certain Type of Feeder?
}

Author(s)
Neves DP'
Nääs IA $A^{1}$
Vercellino R do $A^{1}$
Moura DJ de ${ }^{1}$
1 School of Agriculture Engineering
Cândido Rondon Ave, 501
Barão Geraldo
University of Campinas - UNICAMP

\section{Mail Address}

Irenilza de Alencar Nääs

13083-875. Campinas, SP, Brazil.

E-mail: irenilza@feagri.unicamp.br

\section{Keywords}

Activity, broiler behavior, feeder efficiency, feeding strategic.

\section{ABSTRACT}

This study compared three types of feeders for broilers: Fênix, Tube and Automatic feeders. Bird's feeding behavior and preference were considered in this the evaluation. Preference was assessed by examining birds' behavioral activities, such as eating, standing and lying around the equipments, and meal duration as function of the environmental variables. Data on the behavioral activities and meal size were collected in a broiler commercial farm using a portable video camera, and the direct footages were analyzed. The time spent in each activity, feeding bout duration and time spent near the trough were statistically analyzed using the test of means and medians. Pearson's correlation test was used to evaluate the relationship between ambient environmental data and the time of feeding. A prospective scenario was established and data were pair wised compared to it. There were interactions between environmental characteristics and feeding and lying down activities during the experiment. Eating behavior was more frequent in the area around the Tube feeder. The duration of feeding time was higher when the birds used the Tube feeder ( $214 \pm 28 \mathrm{~s})$, followed by the use of the Fênix feeder $(123 \pm 17 \mathrm{~s})$ and the Automatic feeder (77 $\pm 29 \mathrm{~s})$. Birds preferred eating from the Tube feeder probably due to the absence of the partition grid above the feeder plate.

\section{INTRODUCTION}

Recent progress in the broiler industry relies in the development of genetics, nutrition, health, and management (Murakami et al., 1995). Several studies and proposals have been made to optimize management, including ideal flock density and rearing environment (Lucchese Filho, 1997; Simon, 1997; Goldflus et al., 1997; Lana et al., 2001; Mortari et al., 2002; Pereira et al., 2007).

The feeding behavior of broilers has been studied in relation to feed type (Harlander-Matauschek \& Häuler, 2009), feed restriction (Savory \& Kostal, 2006), different diet types (Siegel et al., 1997; Emmans \& Kyriazikis, 2001; Bouvarel et al., 2008), and the nature of bouts (Nielsen et al., 1995; Yo et al., 1997; Picard et al., 2002). Also the feeding event criteria and its interpretation with respect to feeding bout intervals have been discussed by authors that tried to estimate specific levels of hunger and animal welfare (Slater, 1974; Berdoy, 1993; Nielsen, 1999; Keeling, 2002). However, there is a lack of information on how those variables interact, particularly under specific rearing environmental conditions.

Bigelow \& Houpt (1988) advocate that the feeding behavior needed to be better understood and assessed in order to compare results from different research studies. A feeding bout is an estimation of the period of time during which a meal occurs. It can be grouped in several bouts and standardized allowing comparison between different experiments 
Neves DP, Nääs IA, Vercellino R do A, Moura DJ de
Do Broilers Prefer to Eat from a Certain Type of Feeder?
(Berdoy, 1993). Several techniques have been used to register bird's behavior during feeding, such as direct and videotaped observations as well as beak movement recording (Sowell et al., 1998; Bley \& Bessei, 2008). Although the observation of feeding behavior is relatively simple, the precise determination of meal size and modeling its frequency and interval is a rather difficult task. Howie et al. (2009) discussed the statistical distribution of feeding events and developed a new methodology to estimate feeding bouts when it is not possible to monitor or to identify the proper intervals between visits to the trough (Yeatles et al., 2001).

The Fênix feeder (Inova, 2008) is a manual feeder for broiler developed by Neves \& Trevisan (2007) and it is still in testing and simulation phase, one being the present study. This equipment presents various innovations in relation to manual feeders commercialized nowadays, especially in terms of handling and ergonomics, allowing its throughout the growth phase, avoiding the use of a specific feeder for the chicks in the initial phase. This feeder has a partition grid above the plate for the growing and final phase, but it can be removed for use in the first days of rearing, allowing easy access to the ration for the chicks. The objective of the present study was to identify the preference of broilers to eat from a certain type of feeder by comparing three types of feeders: conventional Tube $(T)$ and Automatic $(A)$ feeders and a newly developed product called Fênix (F). The interaction of feeding with behavioral activities associated with specific rearing environmental conditions was observed, and meal length and frequency were determined.

\section{MATERIALS AND METHODS}

The experiment was carried out in an integrated broiler farm located at latitude $22^{\circ} 26^{\prime} \mathrm{S}$ and longitude $47^{\circ} 32^{\prime} \mathrm{W}$. Local altitude is $635 \mathrm{~m}$ and the climate is characterized by having dry winter and hot and wet summer. The trial was conducted during July, 2009. The studied broiler house was open-sided with EastWest solar orientation, and it was $100 \mathrm{~m}$ long, $8.5 \mathrm{~m}$ wide and $2.8 \mathrm{~m}$ high. It housed 14,000 Ross ${ }^{\circledR}$ broilers at a stocking density of 16 birds $m-2$. Manual chick feeders were used during the starter phase and Tube feeders combined with one line of automatic feeders placed in the center of the house was used during the grower and finisher phases. Water was supplied in bell-type drinkers. The house used circulation fans and lowpressure foggers to control heat stress. Polypropylene curtains on the side walls controlled excessive natural ventilation, sunlight incidence, and the entrance of rain. The concrete floor was covered by Pinus wood-shavings litter.

\section{Feeder characteristics}

Three types of feeders were used in this study: Fênix manual feeder (F), which was recently developed and still not commercially available; conventional Tube manual feeders ( $T$ ) of a local brand and used during the grower-finisher phase; and automatic feeders $(A)$, also of a local brand and used during the growerfinisher phase. Both Fênix and Automatic feeders had a grid partition attached to the trough. The Fênix feeder was setup before of the arrival of the batch. Their dimensions are shown in Table 1.

\section{Experimental procedure}

Video images were recorded using two simultaneous cameras in a pair-wise comparison between the feeders. The following comparisons were made: Fênix (F1) versus Tube (T1) feeders, and Fênix (F2) versus Automatic (A2) feeders. Both F1 and F2 are the same Fênix feeder, but in distinct comparisons (different times). Recording were made for about 55min twice daily, one in the morning (9h00min - 12h00min) and the other in the afternoon (13h00min - 16h00min). However, only $45 \mathrm{~min}$ were used for analysis as the first 10 min were not used to account for human interference on bird behavior during video camera setup. In general, 24 video footages were done in pairs, with a total of 48 footages. The cameras were attached to a metal holder to allow recording birds' activities around the feeders from the top, and the feeders were placed in the center of the recorded area $(1.0 \mathrm{~m}$ by $1.5 \mathrm{~m})$, below the video camera. Images were

\begin{tabular}{|c|c|c|c|c|c|}
\hline \multirow[b]{2}{*}{ Feeder } & \multicolumn{2}{|c|}{ External dimensions (m) } & \multicolumn{3}{|c|}{ Partition grid (m) } \\
\hline & Height & Diameter & Length* & Width** & Quantity \\
\hline Fênix & 0.70 & 0.36 & 0.085 & 0.035 & 9 \\
\hline Tube & 0.60 & 0.42 & NA & NA & NA \\
\hline Automatic & 0.25 & 0.33 & 0.060 & 0.140 & 14 \\
\hline
\end{tabular}

${ }^{*}$ Refers to the horizontal distance of the partition grid. ${ }^{*}$ Refers to the vertical distance of the partition grid. NA $=$ Does not apply. 


\begin{tabular}{|c|c|c|c|c|c|c|c|}
\hline \multirow[b]{2}{*}{ Data type } & \multirow[b]{2}{*}{ Feeder type } & \multicolumn{6}{|c|}{ Behavioral activities } \\
\hline & & Eating & p-Value & Standing up & p-Value & Lying down & p-Value \\
\hline \multirow[t]{4}{*}{ a } & F1 & $6.77 \pm 0.34$ & $0.000 *$ & $1.42 \pm 020$ & $0.05^{*}$ & $6.95 \pm 0.74$ & $0.005^{*}$ \\
\hline & T1 & $8.94 \pm 0.38$ & & $1.29 \pm 0.23$ & & $4.61 \pm 0.36$ & \\
\hline & F2 & $5.77 \pm 0.24$ & $0.000 *$ & $1.26 \pm 0.13$ & $0.001 *$ & $7.15 \pm 0.68$ & $0.000 *$ \\
\hline & A2 & $3.75 \pm 0.29$ & & $0.70 \pm 0.10$ & & $1.68 \pm 0.17$ & \\
\hline \multirow[t]{4}{*}{ b } & F1 & $49.7 \pm 2.4$ & $0.002 *$ & $11.4 \pm 1.7$ & NS & $38.0 \pm 2.4$ & $0.004^{*}$ \\
\hline & T1 & $60.0 \pm 2.2$ & & $10.6 \pm 2.0$ & & $29.4 \pm 1.6$ & \\
\hline & F2 & $46.0 \pm 2.0$ & $0.004 *$ & $10.8 \pm 1.1$ & $0.001 *$ & $43.2 \pm 2.6$ & $0.002 *$ \\
\hline & A2 & $56.8 \pm 3.1$ & & $12.4 \pm 1.6$ & & $30.8 \pm 3.1$ & \\
\hline
\end{tabular}

Student t-test. Data expressed as mean \pm standard error. ${ }^{*} p$-Value $<0.05$; NS = not significant.

digitalized using the VOB extension (DVD/video). The actual area used for analysis was a circle of $0.9 \mathrm{~m}$ diameter surrounding the feeder, which was virtually marked in the video images.

Environmental data (temperature, relative humidity and light intensity) were recorded using a $\mathrm{Hobo}^{\circledR}$ data logger placed $0.30 \mathrm{~m}$ above the floor between the pair feeders analyzed. The data logger was set to record data every 30s, allowing simultaneous recording of video image and environmental variables. Both internal and external air speed were recorded twice daily simultaneously to video recording using a HTA $4200^{\circledR}$ apparatus, been one in the morning e other in the afternoon. Birds were submitted to standard farm management during the trial.

The following behaviors were analyzed based on video image data as follows: (1) three types of behavioral activities in the determined area around the feeders - eating, standing and lying down; (2) birds were randomly selected and followed to determine meal time. In order to analyze behavioral activities, the three previously described behaviors happening during 10 s were quantified every $5 \mathrm{~min}$ of video recording, in a total of nine events per video recording ( $45 \mathrm{~min}$ each). The activity of feeding was characterized as the bird placing its beak inside the feeder. The bird was standing up when it was exploring the area around the feeder, either slowly walking or standing still. Birds were considered to be lying down when resting on the floor. Meal time started to be counted when the bird placed its beak inside the feeder (start of the bout) and stopped when it moved away from the feeder (end of the bout). If it stopped eating for less than 20s and returns to eating, the same bout was considered.

The pullet manual feeders and the Fênix feeder (without grid partition) were used during the first days of rearing. Later, pullet feeders were replaced by Tube feeders, and the partition grid was connected to the Fênix feeder plate. The Automatic feeders were turned on in the third week. From that moment on, birds had access to all feeders, prior to the beginning of the test. The trial was conducted during the steepest segment of the genetic strain growth curve, which corresponded to the interval of approximately 17 to 24 days of age (Goliomytis et al., 2003).

\section{Data analyses}

Tests of means and medians were used to statistically analyze the data and significance was considered when $\alpha \geq 95 \%$. Data were processed using the software MINITAB ${ }^{\circledR} 15.1$ (Minitab, 2005).

Behavioral activities were analyzed by pair-wise comparison between Fênix and Tube feeders and between Fênix and Automatic feeders. Descriptive analysis (mean and standard error) was used. In specific cases, the percentage of birds as function of the total number of birds present in the studied perimeter was used for analysis. Student's t-test was applied for comparative analysis, and Pearson's correlation was used when interactions among period of the day, age and environmental variables were determined. Two environmental temperature limits were considered in the interactions: $\mathrm{L} 1=17 \leq \mathrm{T}\left({ }^{\circ} \mathrm{C}\right) \leq 22 ; \mathrm{L} 2=2<\mathrm{T}\left({ }^{\circ} \mathrm{C}\right)$ $\leq 26)$ defined according to the data recorded during the experiment.

Meal time (MT) was also analyzed using pair-wise comparison between as Fênix (F1) versus Tube (T1) feeders and Fênix (F2) versus Automatic (A2). It was also analyzed for each individual feeder ( $F, T$, and $A)$, using data median for descriptive analysis. Mann-Whitney test was used to compare treatments. The possible interactions between environmental data, age, and period of the day with the behavioral response of the birds was analyzed within the following temperature limits: $\mathrm{L} 1=17 \leq \mathrm{T}\left({ }^{\circ} \mathrm{C}\right) \leq 22 ; \mathrm{L} 2=2<\mathrm{T}\left({ }^{\circ} \mathrm{C}\right) \leq 26$, defined according to the variation of collected data and as function of the time lag $[1=0<\mathrm{MT}(\mathrm{s})<100 ; 2=100<$ MT $(\mathrm{s})<200 ; 3=201<\mathrm{MT}(\mathrm{s})<300 ; 4=\mathrm{MT}(\mathrm{s})<300]$. 
Neves DP, Nääs IA, Vercellino R do A, Moura DJ de

\section{RESULTS AND DISCUSSION}

Results are organized into two sections: behavioral activity analysis and the time the birds spent eating at the feeder.

\section{Behavioral activities}

The Student t-test results of the pair-wise comparison relative to behavioral activities are shown in Table 2. The same test was applied for the percentage of the birds performing each observed activity (Table 3 ). There were significant differences ( $P$ $<0.05$ ) among the behaviors of eating, standing up, and lying down in the area around the feeders. The number of birds eating around the Tube feeders ( $T 1$ ) was higher as compared to the other feeders, whereas the lowest number was recorded around the Automatic (A2) feeders. Standing up was not significantly different among feeders according to the pair-wise comparison, while the lying-down behavior was higher at the Fênix feeder in both trials (F1 and F2) as compared to the other two feeders.

When analyzing the period of the day (morning and afternoon), eating near the Tube feeder (T1) tended to be higher during the afternoon. At the same feeder, a high incidence of the birds standing up in the morning was observed (Table 3). A clear trend of a higher number of birds lying down around the Fênix feeder (F1) was recorded in the afternoon.

There were significant differences among the tested feeders as to the standing activity, despite the observed low frequencies of this behavior. However, it is not clear if these differences can be associated to the type of studied feeders; rather, it is suggested in literature that this may be related to locomotion disorders (Sherwin, 1995; Koene, 1998; Sherwin, 1999; Fiscus Le Van et al. 2000; Martrenchar et al., 2000; PettitRiley and Esteves, 2001). Leg weakness may prevent the expression of natural behavior of chickens to explore the environment and look for food.
The difference in the way animals feed themselves is highly influenced by the design (size, geometry, angle and spacing) and allocation of the equipments (Hyun et al., 1998; Hyun \& Ellis, 2002; Wolter et al., 2009). The social hierarchy in large groups also tends to establish an order of access to feeding, as shown by Pagel \& Dawkins (1997). Nevertheless, in the third and forth weeks of growth, birds are still young and probably do not show much aggression when disputing feed.

The interactions among activity frequencies at the Fênix feeder (F1) and the Tube feeder (T1), as well as feeding and lying down percentages with environmental variables are shown in Table $4 a$. The same analysis for Fênix feeder (F2) and Automatic feeder (A2) is presented in Table 4b. Person's correlation was calculated in order to evaluate the relationship between environmental variables and behavioral activity percentages, differentiating feeder type and broiler age (third and fourth week). In this specific case (Table 5), Pearson's correlation results show the influence of environmental variables (temperature, light intensity, and relative humidity) on behavioral activities. The obtained results suggest that environmental variables influence broiler activity as a function of age (Table 4a,b). Different interactions between environmental data with eating and lyingdown activities when birds were three or four weeks old were found. The most significant interactions obtained were between relative humidity and eating at the Fênix feeder (F1) and Tube feeder (T1) during the third week of rearing $(\mathrm{RH}=69.4 \pm 19.6 \%)$, and between environmental temperature and eating and lying-down at Automatic feeder (A2) during the fourth week of rearing $\left(T=23.7 \pm 1.5^{\circ} \mathrm{C}\right)$.

The minimum influence of thermal environment and the adoption of specific diets in rapid growth broilers are reported as the best ways to improve field performance (Jaenisch, 1998; Vieira et al., 2004; Kidd et al., 2005). Cahaner et al. (1995) suggest that fast-

\begin{tabular}{|c|c|c|c|c|c|c|c|}
\hline \multirow[b]{2}{*}{ Feeder type } & \multicolumn{6}{|c|}{ Behavioral activity } & \multirow[b]{2}{*}{ p-Value } \\
\hline & Period & Eating & p-Value & Standing up & p-Value & Lying down & \\
\hline $\mathrm{F} 1$ & $\begin{array}{l}\text { morning } \\
\text { afternoon }\end{array}$ & $\begin{array}{l}6.17 \pm 0.56 \\
7.37 \pm 0.40\end{array}$ & NS & $\begin{array}{l}1.65 \pm 0.32 \\
1.19 \pm 0.23\end{array}$ & NS & $\begin{array}{c}5.11 \pm 0.66 \\
8.80 \pm 1.3\end{array}$ & $0.013^{*}$ \\
\hline T1 & $\begin{array}{l}\text { morning } \\
\text { afternoon }\end{array}$ & $\begin{array}{l}8.11 \pm 0.64 \\
9.76 \pm 0.61\end{array}$ & $0.032 *$ & $\begin{array}{l}1.93 \pm 0.42 \\
0.65 \pm 0.11\end{array}$ & $0.005^{*}$ & $\begin{array}{l}5.04 \pm 0.55 \\
4.19 \pm 0.46\end{array}$ & NS \\
\hline F2 & $\begin{array}{l}\text { morning } \\
\text { afternoon }\end{array}$ & $\begin{array}{l}5.43 \pm 0.32 \\
6.11 \pm 0.36\end{array}$ & NS & $\begin{array}{l}1.30 \pm 0.18 \\
1.22 \pm 0.18\end{array}$ & NS & $\begin{array}{c}7.54 \pm 1.2 \\
6.76 \pm 0.58\end{array}$ & NS \\
\hline A2 & $\begin{array}{l}\text { morning } \\
\text { afternoon }\end{array}$ & $\begin{array}{l}3.39 \pm 0.40 \\
4.11 \pm 0.41\end{array}$ & NS & $\begin{array}{l}0.83 \pm 0.13 \\
0.57 \pm 0.15\end{array}$ & NS & $\begin{array}{l}1.63 \pm 0.22 \\
1.72 \pm 0.25\end{array}$ & NS \\
\hline
\end{tabular}

Student t-test. Data expressed as mean value \pm standard error. ${ }^{*}$ p-value $<0.05 ;$ NS $=$ not significant. 


\begin{tabular}{|c|c|c|c|c|c|c|c|c|c|c|c|}
\hline \multirow[b]{3}{*}{ Week } & \multirow[b]{3}{*}{ Day } & \multirow[b]{3}{*}{ Data } & \multicolumn{4}{|c|}{ Feeder type } & \multirow{2}{*}{\multicolumn{5}{|c|}{ Environmental variables }} \\
\hline & & & \multicolumn{2}{|c|}{ Fênix } & \multicolumn{2}{|c|}{ Tube } & & & & & \\
\hline & & & Eating & Lying down & Eating & Lying down & $\begin{array}{c}\mathrm{T} \\
\left({ }^{\circ} \mathrm{C}\right)\end{array}$ & $\begin{array}{l}\text { L } \\
(\mid x)\end{array}$ & $\begin{array}{l}\text { RH } \\
(\%)\end{array}$ & $\begin{array}{c}\operatorname{lav} \\
\left(\mathrm{m} \mathrm{s}^{-1}\right)\end{array}$ & $\begin{array}{c}\text { Eav } \\
\left(\mathrm{m} \mathrm{s}^{-1}\right)\end{array}$ \\
\hline \multirow[t]{6}{*}{$3 r d$} & 17 & $\begin{array}{l}a \\
b\end{array}$ & $\begin{array}{c}4.61 \pm 0.82 \\
21.28 \pm 3.45\end{array}$ & $\begin{array}{l}13.44 \pm 3.08 \\
49.47 \pm 6.32\end{array}$ & $\begin{array}{c}6.89 \pm 1.60 \\
46.38 \pm 9.77\end{array}$ & $\begin{array}{c}1.33 \pm 0.32 \\
11.72 \pm 3.22\end{array}$ & $22.4 \pm 1.3$ & $725 \pm 181$ & $58.8 \pm 5.3$ & 0.31 & 1.90 \\
\hline & 18 & a & $5.78 \pm 0.77$ & $0.78 \pm 0.26$ & $7.89 \pm 0.84$ & $4.67 \pm 1.15$ & $18.1 \pm 0.2$ & $61 \pm 3$ & $78.4 \pm 1.8$ & 0.00 & 1.93 \\
\hline & & b & $68.06 \pm 6.41$ & $8.04 \pm 2.49$ & $62.26 \pm 4.88$ & $32.21 \pm 4.14$ & & & & & \\
\hline & 20 & a & $8.56 \pm 0.82$ & $4.33 \pm 0.57$ & $10.61 \pm 0.76$ & $6.89 \pm 1.13$ & $23.4 \pm 0.9$ & $84 \pm 16$ & $72.6 \pm 0.9$ & 0.35 & 1.28 \\
\hline & & b & $65.01 \pm 3.62$ & $32.39 \pm 3.39$ & $59.84 \pm 3.53$ & $35.98 \pm 3.31$ & & & & & \\
\hline & 21 & $\begin{array}{l}a \\
b\end{array}$ & $\begin{array}{c}8.17 \pm 0.85 \\
64.31 \pm 4.09\end{array}$ & $\begin{array}{c}3.39 \pm 0.54 \\
27.65 \pm 3.92\end{array}$ & $\begin{array}{c}9.22 \pm 0.75 \\
64.81 \pm 3.79\end{array}$ & $\begin{array}{c}4.61 \pm 0.70 \\
30.75 \pm 3.67\end{array}$ & $24.4 \pm 0.5$ & $503 \pm 66$ & $67.9 \pm 2.5$ & 0.19 & 1.22 \\
\hline \multirow[t]{3}{*}{ 4th } & 23 & $\begin{array}{l}a \\
b\end{array}$ & $\begin{array}{c}5.72 \pm 0.82 \\
43.34 \pm 4.62\end{array}$ & $\begin{array}{c}5.89 \pm 0.71 \\
48.36 \pm 5.56\end{array}$ & $\begin{array}{c}8.28 \pm 0.60 \\
62.26 \pm 4.22\end{array}$ & $\begin{array}{c}4.61 \pm 0.70 \\
33.17 \pm 4.12\end{array}$ & $25.8 \pm 0.2$ & $460 \pm 55$ & $64.2 \pm 0.9$ & 0.25 & 0.63 \\
\hline & 24 & a & $7.78 \pm 0.63$ & $13.89 \pm 1.11$ & $10.72 \pm 0.39$ & $5.56 \pm 0.52$ & $23.8 \pm 0.6$ & $524 \pm 84$ & $66.0 \pm 2.2$ & 0.65 & 0.84 \\
\hline & & b & $36.46 \pm 3.24$ & $61.80 \pm 3.34$ & $64.44 \pm 2.13$ & $32.71 \pm 2.46$ & & & & & \\
\hline & & & \multicolumn{2}{|c|}{ Fênix } & \multicolumn{2}{|c|}{ Automatic } & & & & & \\
\hline \multirow[t]{5}{*}{$3 \mathrm{rd}$} & 17 & $\begin{array}{l}a \\
b\end{array}$ & $\begin{array}{c}6.72 \pm 0.66 \\
61.68 \pm 2.71\end{array}$ & $\begin{array}{c}1.83 \pm 0.31 \\
16.21 \pm 2.55\end{array}$ & $\begin{array}{c}2.78 \pm 0.51 \\
48.54 \pm 7.74\end{array}$ & $\begin{array}{c}1.5 \pm 0.46 \\
31.03 \pm 7.99\end{array}$ & $22.7 \pm 0.4$ & $321 \pm 58$ & $55.9 \pm 1.3$ & 0.31 & 1.90 \\
\hline & 18 & $\begin{array}{l}a \\
b\end{array}$ & $\begin{array}{c}6.06 \pm 0.50 \\
57.67 \pm 4.63\end{array}$ & $\begin{array}{c}2.89 \pm 0.82 \\
23.87 \pm 5.49\end{array}$ & $\begin{array}{c}2.78 \pm 0.36 \\
77.12 \pm 5.67\end{array}$ & $\begin{array}{l}0.17 \pm 0.09 \\
5.28 \pm 3.14\end{array}$ & $17.7 \pm 0.2$ & $36 \pm 4$ & $80.5 \pm 0.7$ & 0.00 & 1.93 \\
\hline & 20 & a & $4.61 \pm 0.47$ & $17.17 \pm 2.14$ & $2.11 \pm 0.56$ & $2.61 \pm 0.49$ & $22.9 \pm 0.8$ & $38 \pm 4$ & $74.7 \pm 0.5$ & 0.35 & 1.28 \\
\hline & & b & $25.49 \pm 4.22$ & $73.63 \pm 4.40$ & $33.73 \pm 6.88$ & $54.51 \pm 7.78$ & & & & & \\
\hline & 21 & $\begin{array}{l}a \\
b\end{array}$ & $\begin{array}{c}6.61 \pm 0.65 \\
49.81 \pm 3.99\end{array}$ & $\begin{array}{c}5.67 \pm 0.57 \\
43.32 \pm 3.89\end{array}$ & $\begin{array}{c}6.17 \pm 0.47 \\
72.59 \pm 3.90\end{array}$ & $\begin{array}{c}2.00 \pm 0.35 \\
21.68 \pm 3.66\end{array}$ & $25.0 \pm 0.2$ & $354 \pm 45$ & $66.0 \pm 0.8$ & 0.19 & 1.22 \\
\hline \multirow[t]{3}{*}{4 th } & 23 & $\begin{array}{l}a \\
b\end{array}$ & $\begin{array}{c}4.94 \pm 0.49 \\
46.12 \pm 4.46\end{array}$ & $\begin{array}{c}5.28 \pm 0.79 \\
43.94 \pm 5.41\end{array}$ & $\begin{array}{c}6.72 \pm 0.64 \\
76.47 \pm 4.04\end{array}$ & $\begin{array}{c}1.33 \pm 0.20 \\
17.69 \pm 3.56\end{array}$ & $24.4 \pm 0.2$ & $399 \pm 36$ & $70.9 \pm 1.9$ & 0.25 & 0.63 \\
\hline & 24 & a & $5.67 \pm 0.64$ & $10.06 \pm 1.27$ & $1.94 \pm 0.68$ & $2.44 \pm 0.44$ & $22.7 \pm 0.4$ & $321 \pm 58$ & $55.9 \pm 1.3$ & 0.65 & 0.84 \\
\hline & & b & $35.05 \pm 3.61$ & $58.39 \pm 4.71$ & $32.25 \pm 7.94$ & $54.60 \pm 8.89$ & & & & & \\
\hline
\end{tabular}

$\mathrm{T}$ = temperature; $\mathrm{L}=$ luminosity; $\mathrm{RH}=$ humidity; lav = internal air velocity; Eav = external air velocity.

Table $\mathbf{5}$ - Interaction between the percentage of eating and lying down behavioral activities in the pair-wise comparison of Fênix (F1) versus Tube (T1) feeders and Fênix (F2) versus Automatic (A2) feeders as a function of rearing age and environmental variable.

\begin{tabular}{|c|c|c|c|c|c|c|c|c|c|c|c|c|}
\hline \multirow[b]{2}{*}{ Week } & \multirow[b]{2}{*}{ Type } & \multirow[b]{2}{*}{ Activity } & \multicolumn{10}{|c|}{ Pearson's correlation } \\
\hline & & & $\begin{array}{c}\mathrm{T} \\
\left({ }^{\circ} \mathrm{C}\right)\end{array}$ & P-value & $\begin{array}{l}L \\
(I x)\end{array}$ & p-value & $\begin{array}{c}\text { RH } \\
(\%)\end{array}$ & p-value & $\begin{array}{c}\text { lav } \\
(m \text { s-1) }\end{array}$ & p-value & $\begin{array}{c}\text { Eav } \\
(m s-1)\end{array}$ & p-value \\
\hline \multirow[t]{9}{*}{$3 r d$} & \multirow[t]{2}{*}{ F1 } & eating & -0.2 & NS & -0.4 & $0.001 *$ & $0.6 * *$ & $0.000 *$ & -0.4 & $0.003 *$ & -0.2 & NS \\
\hline & & lying down & 0.3 & $0.017^{\star}$ & 0.1 & NS & -0.3 & $0.005^{*}$ & 0.4 & $0.000 *$ & 0.2 & NS \\
\hline & \multirow[t]{2}{*}{ T1 } & eating & -0.3 & $0.004^{*}$ & -0.5 & $0.000 *$ & $0.5 * *$ & $0.000 *$ & -0.3 & 0.037 * & 0.5 & $0.000 *$ \\
\hline & & lying down & 0.1 & NS & -0.1 & NS & 0.3 & $0.010 *$ & -0.2 & NS & -0.4 & $0.000 *$ \\
\hline & \multirow[t]{3}{*}{$\mathrm{F} 2$} & comendo & & & & & & & & & & \\
\hline & & eating & -0.2 & NS & 0.2 & $0.037 *$ & -0.3 & $0.015^{*}$ & -0.3 & $0.004 *$ & 0.2 & NS \\
\hline & & lying down & 0.3 & $0.016 *$ & -0.3 & $0.017 *$ & 0.3 & $0.009 *$ & 0.3 & $0.012 *$ & -0.2 & 0.041 * \\
\hline & \multirow[t]{2}{*}{ A2 } & eating & -0.2 & NS & 0.2 & NS & 0.1 & NS & -0.4 & 0.001 * & -0.1 & NS \\
\hline & & lying down & 0.3 & $0.008 *$ & -0.1 & NS & -0.1 & NS & 0.4 & 0.001 * & -0.0 & NS \\
\hline \multirow[t]{8}{*}{ 4th } & \multirow[t]{2}{*}{$\mathrm{F} 1$} & eating & 0.1 & NS & 0.2 & NS & 0.2 & NS & -0.1 & NS & 0.1 & NS \\
\hline & & lying down & -0.2 & NS & 0.1 & NS & -0.1 & NS & 0.2 & NS & -0.1 & NS \\
\hline & \multirow[t]{2}{*}{ T1 } & eating & -0.2 & NS & 0.2 & NS & 0.3 & NS & 0.1 & NS & 0.1 & NS \\
\hline & & lying down & 0.1 & NS & -0.1 & NS & -0.3 & NS & -0.1 & NS & -0.0 & NS \\
\hline & \multirow[t]{2}{*}{ F2 } & eating & 0.3 & NS & -0.1 & NS & -0.1 & NS & -0.3 & NS & -0.2 & NS \\
\hline & & lying down & -0.3 & NS & 0.2 & NS & 0.1 & NS & 0.4 & 0.024 * & 0.2 & NS \\
\hline & \multirow[t]{2}{*}{ A2 } & eating & $0.8 * *$ & $0.000 *$ & 0.0 & NS & -0.2 & NS & -0.1 & NS & $-0.5 * *$ & 0.001 * \\
\hline & & lying down & $-0.8 * *$ & $0.000 *$ & -0.1 & NS & 0.3 & NS & 0.0 & NS & $0.6 * *$ & $0.000 *$ \\
\hline
\end{tabular}

$\mathrm{T}=$ temperature; $\mathrm{L}=$ luminosity; $\mathrm{RH}=$ relative humidity; lav = internal air velocity; Eav = external air velocity. ${ }^{\star} \mathrm{p}-\mathrm{value}<0.05 ; \star *$ Significant interaction; NS = not significant.

growing broiler genetic strains are more sensitive to environmental temperature changes and extremes, especially under tropical rearing conditions, as determined by Macari \& Furlan (2001). Therefore, under this specific scenario, environmental temperature could have been a limiting factor of the activity of eating recorded in the present study.

Table 6 presents the differences in eating and lyingdown behavioral activities between environmental temperature limits of $\mathrm{L} 1=17 \leq \mathrm{T}\left({ }^{\circ} \mathrm{C}\right) \leq 22$ and $\mathrm{L} 2=22$ $<\mathrm{T}\left({ }^{\circ} \mathrm{C}\right) \leq 26$. The Student t-test revealed that eating activity at the Tube feeder (T1) was higher at low 


\section{Neves DP, Nääs IA, Vercellino R do A, Moura DJ de}

Do Broilers Prefer to Eat from a Certain Type of Feeder? environmental temperatures (L1), and that the opposite occurred at the Automatic feeder (A2), where the activity of eating was higher when environmental temperatures were higher than normal (L2). As to the Fênix feeder (F2), the results suggest that the activity of lying down was more frequent when temperatures were low (L1).

These results as different from those found by Rutz (1994), who observed that birds tended to reduce both feed intake and locomotor activity as environmental temperature increased, as also found by Curto et al. (2007), in a study with broiler breeders. In the present study, the recorded environmental temperatures were never above above $30{ }^{\circ} \mathrm{C}$, which may indicate that ambient temperature did not limit feed intake, especially considering that young birds are more tolerant to high ambient temperatures and did not present heat stress signs (Lasiewski et al., 1966; Baião, 1995). In the present study, it was observed that when environmental temperatures were low, eating activity increased at the Tube feeder (T1) and decreased in Automatic feeder (A2), while the laying down activity increase in low temperatures in the Fênix feeder (F2). When temperature was low, the frequency of birds lying down and huddling in the surroundings of the feeders increased, as shown by Curtis (1983).

\section{Analysis of meal length}

Considering feeding bout times of the three group of broilers as $1=0<\mathrm{TM}(\mathrm{s})<100,2=100<\mathrm{TM}(\mathrm{s})<$ 200, $3=201<\mathrm{TM}(\mathrm{s})<300,4=\mathrm{TM}(\mathrm{s})<300$, and removing avoiding the outliers, median feeding time bout was $124.5 \pm 28.7 \mathrm{~s}$ (median \pm standard error), which is within time 1 . Table 7 shows feeding bout duration according to birds' age and feeder type ( $\mathrm{F}, \mathrm{T}$, and A). Considering time 1 as optimal feeding bout duration, feeder A provided the best meal time, followed by the Fênix feeder ( $F$ ) and the Tube feeder (T). Although feeding bout duration at the automatic feeder was higher than time $1[0 \leq \mathrm{TM}(\mathrm{s}) \leq 100]$, which is considered as optimal, nearly $50 \%$ of the feeding bouts occurred in less than 30s, which suggest that these bouts were excessively short to be considered an appropriate meal. Both at the Fênix and the Tube feeders, the percentages of feeding bouts occurring within that time range (time 1) were approximately 35 and $20 \%$, respectively. Feeding bout duration at the Fênix feeder was significant closer to the time median ( $p$-value <0.05) as compared to the other feeders. In general, the shortest median time of a feeding bout was spent at the Automatic feeder (77 $\pm 29 \mathrm{~s})$, followed by the Fênix feeder $(123 \pm 17 \mathrm{~s})$, and the Tube feeder $(214 \pm 28 s)$. As broilers are not submitted to feed restriction at this age, the length of the meal may vary, according to Nielsen (1999) and Keeling (2002).

\begin{tabular}{|c|c|c|c|c|c|c|}
\hline \multirow[b]{2}{*}{ Week } & \multirow[b]{2}{*}{ Feeder } & \multirow[b]{2}{*}{ Data type } & \multicolumn{4}{|c|}{ Time range } \\
\hline & & & 1 & 2 & 3 & 4 \\
\hline \multirow[t]{6}{*}{$3 r d$} & Fênix & a & $11 *$ & 9 & 6 & 6 \\
\hline & & b & $34.4^{*}$ & 28.1 & 18.7 & 18.7 \\
\hline & Tube & a & 7 & 4 & 8 & $13 *$ \\
\hline & & b & 21.9 & 12.5 & 25.0 & $40.6^{*}$ \\
\hline & Automatic & a & $20 *$ & 6 & 3 & 3 \\
\hline & & b & $62.5^{*}$ & 18.7 & 9.4 & 9.4 \\
\hline \multirow[t]{6}{*}{4 th } & Fênix & a & 6 & $7 *$ & 2 & 1 \\
\hline & & b & 37.5 & 43.7 * & 12.5 & 6.2 \\
\hline & Tube & a & $6 *$ & 5 & 2 & 3 \\
\hline & & b & $37.5^{*}$ & 31.35 & 12.5 & 18.75 \\
\hline & Automatic & a & $9 *$ & 2 & 2 & 3 \\
\hline & & b & $56.3 *$ & 12.5 & 12.5 & 18.7 \\
\hline \multirow[t]{6}{*}{ Total } & Fênix & $a$ & $17^{*}$ & 16 & 8 & 7 \\
\hline & & b & $35.4^{*}$ & 33.3 & 16.7 & 14.6 \\
\hline & Tube & a & 13 & 9 & 10 & $16 *$ \\
\hline & & b & 27.1 & 18.7 & 20.8 & $33.3 *$ \\
\hline & Automatic & a & $29 *$ & 8 & 5 & 6 \\
\hline & & $b$ & $60.4 *$ & 16.7 & 10.4 & 12.5 \\
\hline
\end{tabular}

Time range $=1=0<\mathrm{t}(\mathrm{s})<100 ; 2=100<\mathrm{t}(\mathrm{s})<200 ; 3=201<\mathrm{t}$ (s) $<300 ; 4=\mathrm{t}(\mathrm{s})<300$. Total $=3 \mathrm{rd}$ and 4 th weeks. ${ }^{*}$ Larger frequency of use by the broilers.

The Mann-Whitney test revealed that feeding bout durations at the Fênix (F) feeder were significantly different between the morning and the afternoon (Table 8). The analysis of the interactions between feeding bout duration at the feeders and environmental variables was carried out pair-wise (F1 versus T1, and F2 versus $A 2$ ). The results of the Pearson's correlation

\begin{tabular}{|c|c|c|c|c|c|c|}
\hline \multirow[b]{3}{*}{ Feeder type } & \multicolumn{5}{|c|}{ Behavioral activity } & \\
\hline & \multicolumn{3}{|c|}{ Eating } & \multicolumn{3}{|c|}{ Lying down } \\
\hline & L1 & $\mathrm{L2}$ & p-value & L1 & L2 & p-value \\
\hline $\mathrm{F} 1$ & $7.24 \pm 0.53$ & $6.43 \pm 0.45$ & NS & $8.20 \pm 1.60$ & $6.03 \pm 0.58$ & NS \\
\hline T1 & $10.49 \pm 0.54$ & $7.83 \pm 0.50$ & $0.000 *$ & $4.80 \pm 0.73$ & $4.48 \pm 0.33$ & NS \\
\hline $\mathrm{F} 2$ & $5.81 \pm 0.42$ & $5.75 \pm 0.29$ & NS & $9.70 \pm 1.70$ & $5.82 \pm 0.50$ & $0.031^{\star}$ \\
\hline $\mathrm{A} 2$ & $1.97 \pm 0.30$ & $4.68 \pm 0.36$ & $0.000 *$ & $1.78 \pm 0.32$ & $1.62 \pm 0.19$ & NS \\
\hline
\end{tabular}

$\mathrm{L} 1=17^{\circ} \leq \mathrm{T}\left({ }^{\circ} \mathrm{C}\right) \leq 22 ; \mathrm{L} 2=22^{\circ}<\mathrm{T}\left({ }^{\circ} \mathrm{C}\right) \leq 26$. Data are expressed as mean \pm standard error. ${ }^{*} \mathrm{p}$-value $<0.05 ; \mathrm{NS}=$ not significant. 


\section{Neves DP, Nääs IA, Vercellino R do A, Moura DJ de}

test applied to the mentioned interactions are shown in Table 9, indicating that light intensity influences meal duration when birds were four weeks of age. The most significant interactions were obtained with light intensity $(432 \pm 32 \mathrm{~lx})$ at the Fênix (F1) and the Tube (T1) feeders and with air velocity $\left(0.45 \pm 0.1 \mathrm{~m} \mathrm{~s}^{-1}\right)$ just at the Fênix (F1) feeder at the 4th week of rearing.

\begin{tabular}{lccc}
\hline Table 8 - Median meal time of birds eating at the Fênix, Tube or \\
Automatic feeders according to period (morning or afternoon). \\
\cline { 2 - 4 } \\
\cline { 2 - 4 } Feeder type & \multicolumn{4}{c}{ Time of meal (s) } \\
Fênix & $173 \pm 23$ & $95 \pm 25$ & p-Value \\
Tube & $201 \pm 37$ & $231 \pm 42$ & NS \\
Automatic & $57 \pm 45$ & $89 \pm 38$ & NS \\
\hline
\end{tabular}

Mann-Whitney test. Data expressed as median \pm standard error. ${ }^{*} p$-value $<0.05$; NS = not significant.

Light intensity may vary from 5 to $100,0001 x$ inside broiler houses (Prescott \& Wathes, 1999; Théry, 2001). The recommended value established by FAWC (1992) is around 20lx. Kristensen et al. (2007) suggested that broilers are not influenced by light intensity, and that their behavioral activities are rather related to other factors, such as health, motivation, and age. Davis et al. (1999) found that young broilers (2 weeks old) prefer low light intensity. Similar findings were obtained by Vanderberg \& Widowski (2000) and Prayitno et al. (1997). In the present study, birds were exposed to a wide range of light intensities, as natural sunlight was the only source of light, which varied from 36 to $7251 x$ during the experiment. This probably contributed to the wide variation in behavioral activities found in the results.

\section{CONCLUSIONS}

Birds preferred to eat from the Tube feeder. Eating behavioral activity was more frequent in the Tube feeder, followed by the Fênix feeder, and the Automatic feeder. This activity was more frequent during the morning and at low ambient temperatures, with the exception of the birds surrounding the Automatic feeder, which ate more frequently when environmental temperatures were high.

Eating bout and meal duration was in general higher at the Tube feeder than at the other two feeders, which may be related to the fact that this feeder does not have the partition grid, allowing the bird full access to the feed.

\section{REFERENCES}

Baião NC. Efeitos da densidade populacional sobre o ambiente das instalações avícolas. Anais do Simpósio Internacional sobre Ambiência e Instalação na Avicultura Industrial; 1995; Campinas. São Paulo. Brasil. p.67.

Berdoy M. Defing bouts of behaviour: a three process model. Animal Behaviour 1993; 46:387-396.

Bigelow JA, Houpt TR. Feeding and drinking patterns in young pigs. Physiology \& Behavior 1988; 43:99-109.

Bley TAG, Bessei W. Recording of individual feed intake and feeding behavior of Pekin ducks kept in groups. Poultry Science 2008; $87: 215-221$

Bouvarel I, Valle C, Chagneau AM, Constantin P, Lescoat P, Ferreira $G$, LEterrier C. Effects of various energy and protein levels during sequential feeding on feed preferences in meat-type chickens. Animal 2008; 11:1674-1681.

Cahaner A, Pinchasov Y, Nir I. Effects of dietary protein under high ambient temperature on body weight, breast meat yield and abdominal fat deposition on broiler stock differing in growth rate and fatness. Poultry Science 1995; 74:968-975.

Table 9 - Interaction of of meal time in the pair-wise comparison of Fênix (F1) versus Tube (T1) feeders and Fênix (F2) versus Automatic (A2) feeders according to age and environmental variables.

\begin{tabular}{|c|c|c|c|c|c|c|c|c|c|c|c|}
\hline \multirow[b]{2}{*}{ Week } & \multirow[b]{2}{*}{ Feeder type } & \multicolumn{9}{|c|}{ Pearson's correlation } & \multirow[b]{2}{*}{ p-value } \\
\hline & & $\begin{array}{c}\mathrm{T} \\
\left({ }^{\circ} \mathrm{C}\right)\end{array}$ & p-value & $\begin{array}{c}\mathrm{L} \\
(\mathrm{Ix})\end{array}$ & p-value & $\begin{array}{c}\text { UR } \\
(\%)\end{array}$ & p-value & $\begin{array}{c}\text { lav } \\
\left(\mathrm{m} \mathrm{s}^{-1}\right)\end{array}$ & p-value & $\begin{array}{c}\text { Eav } \\
\left(\mathrm{m} \mathrm{s}^{-1}\right)\end{array}$ & \\
\hline \multirow[t]{4}{*}{$3 r d$} & $\mathrm{~F} 1$ & 0.2 & NS & -0.1 & NS & -0.0 & NS & 0.145 & 0.428 & -0.169 & NS \\
\hline & T1 & -0.1 & NS & -0.3 & NS & 0.3 & NS & -0.201 & 0.269 & -0.082 & NS \\
\hline & $\mathrm{F} 2$ & 0.0 & NS & -0.2 & NS & 0.2 & NS & 0.151 & 0.411 & $0.020 *$ & NS \\
\hline & $A 2$ & 0.0 & NS & -0.0 & NS & 0.1 & NS & -0.361 & $0.042 *$ & -0.125 & NS \\
\hline \multirow[t]{4}{*}{ 4th } & $\mathrm{F} 1$ & -0.4 & NS & $-0.5 * *$ & 0.047 * & 0.4 & NS & -0.253 & 0.344 & $0.586 * *$ & $0.017 *$ \\
\hline & T1 & -0.2 & NS & $0.6 * *$ & 0.024 * & -0.2 & NS & $0.699 * *$ & $0.003 *$ & -0.299 & NS \\
\hline & $\mathrm{F} 2$ & 0.1 & NS & -0.3 & NS & 0.1 & NS & -0.429 & 0.097 & -0.123 & NS \\
\hline & $\mathrm{A} 2$ & 0.3 & NS & 0.2 & NS & -0.2 & NS & 0.082 & 0.764 & -0.208 & NS \\
\hline \multirow[t]{4}{*}{ Total } & F1 & -0.0 & NS & -0.1 & NS & 0.1 & NS & -0.057 & 0.702 & 0.035 & NS \\
\hline & T1 & -0.2 & NS & -0.2 & NS & 0.3 & NS & -0.039 & 0.791 & 0.084 & NS \\
\hline & $\mathrm{F} 2$ & -0.1 & NS & -0.3 & 0.030 * & 0.2 & NS & -0.118 & 0.424 & 0.133 & NS \\
\hline & $A 2$ & -0.1 & NS & 0.1 & NS & 0.1 & NS & -0.096 & 0.516 & -0.170 & NS \\
\hline
\end{tabular}

$\mathrm{T}=$ temperature; $\mathrm{L}=$ luminosity; $\mathrm{RH}=$ relative humidity; lav = internal air velocity; Eav = external air velocity. ${ }^{*} \mathrm{p}$-value $<0.05 ;{ }^{*}$ Significant interaction > 0.5; NS $=$ not significant. 


\section{Neves DP, Nääs IA, Vercellino R do A, Moura DJ de}

Curtis SE. Environmental management in animal agriculture. lowa: lowa State University Press; 1983.

Curto FPF, Nääs IA, Pereira DF, Salgado DD. Estimativa do padrão de preferência térmica de matrizes pesadas (frango de corte). Revista Brasileira de Engenharia Agrícola e Ambiental 2007; 11 (2):211-216.

Davis NJ, Prescott NB, Savory CJ, Wathes CM. Preferences of growing fowls for different light intensities in relation to age, strain and behaviour. Animal Welfare 1999; 8:193-203.

Emmans GC, Kyriazakis I. Consequences of gentic change in farm animals on food intake and feeding behaviour. Proceedings of Nutricion Society. Cork, Republic of Ireland 2001; (60):115-125.

FARM ANIMAL. WELFARE COUNCIL. Report on the welfare of broiler chickens. Ministry of Agriculture, Fisheries and Food; 1992. p.9.

Fiscus Le Van N, Esteves I, Strickling WR. Use oh horizontal and angled perches by broiler chickens. Applied Animal. Behaviour Science 2000; 65:359-365.

Goldflus F, Ariki J, Krona SN. Efeitos de diferentes densidades populacionais nas estações fria e quente do ano sobre o desempenho de frangos de corte. Revista Brasileira de Zootecnia 1997; 26(5):948-954.

Goliomytis M, Panopoulou E, Rogdakis E. Growth curves for body weight and major component parts, feed consumption, and mortality of male broiler chickens raised to maturity. Poultry Science 2003; 82:1061-1068.

Harlander-Matauschek A, Häusler K. Understanding feather eating behavior in laying hens. Applied. Animal. Behaviour Science 2009; 117:35-41.

Howie JA, Tolkamp BJ, Avendaño S, Kyriazakis I. A novel flexible method to split feeding behavior into bouts. Applied. Animal. Behaviour. Science 2009; 116:101-109.

Hyun $Y$, Ellis M. Effect of group size and feeder type on growth performance and feeding patterns in finishing pigs. Journal of Animal Science 2002; 80:568-574.

Hyun Y, Ellis M, Johnson RW. Effects of feeder type, space allowance and mixing on the growth performance and feed intake pattern of growing pigs. Journal of Animal Science 1998; 76:2771-2778.

Neves DP, Nääs IA, Tamura JY, Trevisan GP. Equipamento manual para avicultura. BR n. PI0806115-7. Campinas, SP: UNICAMP; 2008.

Jaenisch FRF. Biossegurança e cuidados sanitários para frangos. Concórdia, SC. EMBRAPA_CNPSA; 1998. p.1-2. (Instrução Técnica para o Avicultor, 6).

Keeling L. Behaviour of fowl and other domesticated birds. In Jensen, $P$, editor. The ethology of domestic animals: an introductory text. Oxon: Cabi Publishing; 2002. p.107-108.

Kidd MT, Corzo A, Hoehler D, Emiller ER, Dozier WA. Broiler responsiveness (Ross $\times 708$ ) to diets varying in amino acid density. Poultry Science 2005; 84:1389-1396.
Koene P. When feeding is just eating: how do farm and zoo animal use their spare time. Proceedings of the 5th Zodiac Symposium on Regulation of Feed Intake; 1998; Wageningen. Holanda. p.13-19.

Kristensen HH, Prescott NB, Perry GC, Ladewig J, Ersbøll AK, Overvad KC, Wathes CM. The behavior of broiler chickens in different light sources and illuminances. Applied Animal Behaviour Science 2007; 103:75-89.

Lana GRQ, Silva Junior RGC, Valerio SR, Lana AMQ, Cordeiro ECGB. Efeito da Densidade e de Programas de Alimentação sobre o Desempenho de Frangos de Corte. Revista Brasileira de Zootecnia 2001; 30(4):1258-1265.

Lasiewski A, Acosta L, Bernstein MH. Evaporative water loss in birds I. Characteristics of the open flow method of determination, and their relation to estimates of thermoregulatory ability. Comparative Biochemistry and Physiology 1966; 19(1):445-457.

Lucchese Filho A. Criação de frangos de corte em alta densidade: pré requisitos, vantagens e desvantagens do sistema. Anais do Manejo de Frangos de Corte; 1997; Campinas. São Paulo. Brasil. Campinas: FACTA; 1997. p.13-22.

Macari M, Furlan RL. Ambiência na produção de aves em clima tropical. In: Silva IJO, editor. Ambiência na produção de aves em clima tropical: Série Engenharia Agrícola Construções Rurais. Piracicaba, SP: SBEA; 2001. p. 31-87.

Martrenchar A, Huonnic D, Cotte JP, Boilletot E, Morisse JP. Influence of stoking density, artificial dusk and group size on the perching behavior of broilers. Brazilian Poultry Science 2000; 41:125-130.

MINITAB. Version 15.1.0.0; 2005.

Mortari AC, Rosa AP, Zanella I, Neto CB, Visentini PR, Brites LBP Desempenho de frangos de corte criados em diferentes densidades populacionais, no inverno, no sul do Brasil. Ciência Rural 2002; 32 (3):493-497.

Murakami AE, Nerilo N, Furlan AC, Scapinello C, Barbosa MJB, Cardoso A. Desempenho, rendimento de carcaça, cortes e desossa de três linhagens comerciais de frangos de corte. Anais da Conferência APINCO de Ciência e Tecnologia Avícolas; 1995; Curitiba. Paraná. Brasil. p.279-280.

Neves DP, Trevisan GP. Redesign de comedouros utilizados na criação de frangos de corte no Brasil [monografia]. Curitiba(PR): Universidade Positivo; 2007.

Nielsen BL. On the interpretation of feeding behaviour measures and the use of feeding rate as an indicator of social constraint. Applied Animal Behaviour Science 1999; 63:79-91.

Nielsen BL, Lawrence AB, Whittemore CT. Effects of single-space feeder design of feeding behaviour and performance of growing pigs. Animal Science 1995; 61:575-579.

Pagel M, Dawkins MS. Peck orders and group size in laying hens: future contracts for non-aggression. Behavioural Processes 1997; 40:13-25. 


\section{Neves DP, Nääs IA, Vercellino R do A, Moura DJ de}

Pereira DF, Nääs IA, Salgado DD, Gaspar CR, Bighi CA, Penha NLJ. Correlations among behavior, performance and environment in broiler breeders using multivariate analysis. Brazilian Journal of Poultry Science 2007; 9(4):207-213.

Picard M, Melcion JP, Bertrand D, Faure JM. Visual and tactile cues perceived by chickens. Poultry Feedstuffs 2002; (supply):279-298.

Prayitno DS, Phillips CJC, Omed $\mathrm{H}$. The effects of color of lighting on the behaviour and production oh meat chickens. Poultry Science 1997; 76:1674-1681

Prescott NB, Watches CM. Reflective properties of domestic fowl (Gallus g. domesticus), the fabric of their housing and the characteristics of the light environment in the environmentally controlled poultry houses. Brazilian Poultry Science 1999; 40:185193.

Rutz F. Aspectos fisiológicos que regulam o conforto térmico de aves. Anais da Conferência APINCO de Ciência e Tecnologia Avícolas; 1994. Santos. São Paulo. Brasil. p.99-100.

Savory JC, Kostal L. Broiler breeder chickens show apparently abnormal behaviours when subjected to routine quantitative food restriction during rearing. Physiology \& Behaviour 2006; 88(45):473-478

Sherwin CM. Environmental enrichment for laying hens - spherical objects in the feed trough. Animal Welfare 1995; 4:41-51.

Sherwin CM, Lewis PD, Perry GC. The effects of environmental enrichment and intermittent lighting on the behavior and welfare of male domestic turkeys, Applied Animal Behaviour Science 1999; 62:319-333.

Siegel PB, Picard M, Nir I, Dunnington EA, Willemsen MHA, Williams PEV. Responses of meat-type chickens to choice feeding of diets differing in protein and energy from hatch to market weight. Poultry Science 1997; 76:1183-1192.

Simon VA. Aspectos sanitários de criações em altas densidades. Anais do Simpósio sobre Ambiência, Sanidade E qualidade de Carcaça de Frangos de Corte; 1997; Concórdia. Santa Catarina. Brasil. p.14-18.

Slater PJB. The temporal pattern of feeding in the Zebra "nch. Animal Behaviour 1974; 22:506-515.

Sowell BF, Bowman JGP, Branine ME, Hubbert ME. Radio frequency technology to measure feeding behavior and health of feedlot steers. Applied Animal Behaviour Science 1998; 59:277-284.

Vandenberg C, Widowski TM. Hen's preferences for high-intensity high-pressure sodium or low- intensity incandescent lighting. The Journal of Applied Poultry Research 2000; 9: 172-178.

Vieira SL, Lemme A, Goldenberg DB, Brugalli I. Responses of growing broilers to diets with increased sulfur amino acids to lysine ratios at two dietary protein levels. Poultry Science 2004; 83:13071313.

Wolter BF, Ellis M, Curtis SE, Parr EN, Webel DM. Feeder location did not affect performance of weaning pigs in large groups. Journal of Animal Science 2009; 78:2784-2789.

Yeatles MP, Tolkamp BJ, Allcroft DJ, Kyriazakis I. The use of mixed distribution models to determine bout criteria for analyses of animal behaviour. Journal of Theoretical Biology 2001; 213:413-435.

Yo T, Vilarino M, Faure JM, Picard M. Feed pecking in young chickens: new techniques of evaluation. Physiology \& Behavior 1997; 61: 803-810 